\title{
CONTEXT OF MUSEOLOGY IN SOCIAL ENTREPRENEURSHIP IBS STUDY IN NEPAL AND SANDAL PRIVATE MUSEUM
}

\author{
Achyut Nepal \\ Affiliated Honorary Research Fellow, Fil. Dr. Jan-U. Sandal Institute, Norway \\ e-mails: achyutnepal1962@gmail.com; provost@jansandal.no
}

Received: 07 October 2020; Accepted: 20 October 2020 Published: 01 January 2021

\begin{abstract}
Important aspects of museology or museum science are Collection Management, Documentation, Conservation Management and Exhibition Management. Fundamental objective of museology is collection, preservation and management of tangible and intangible form of natural, historical, cultural and scientific objects as well as intellectual work and knowledge for education. Collecting, preserving and managing the output of every scientific field is possible by Museum Science. Museum today is not the mere place of collecting and preserving the art work and cultural objects but becoming effective mode of informal education and communication. Basic objective of this paper is to delve into the different aspects of museum science, social entrepreneurship education in Nepal and contribution of Sandal Institute and museum. The methodology adopted is review of literature and cases as well as interviews. In this paper basic aspect of museology, importance of preserving objects with museum values has been discussed along with the context of social entrepreneurship and contribution of Fil. Dr. Jan-U. Sandal Institute in this field and it's context of Nepal as well. Entrepreneurs with their self-motivation and judgmental decision create innovation and are the creator of civilization. Education in the subject of Social Entrepreneurship is crucial to understand the role of entrepreneurship in social transformation. Study on the life and work of entrepreneurs is utmost important to understand the process of innovation. Establishment of Sandal Private Museum is an important initiation in this field and this will not only help the education of school students but education to educated individual in the entire sphere of the societies.
\end{abstract}

Keywords: Artifacts, Innovation, Entrepreneur, Social, Museology, Museum, Science.

JEL classification: A12; A31; F54; L26; L31; O31; O35; Z11

\section{Citation:}

Nepal, A. 2021. Context of museology in social entrepreneurship IBS study in Nepal and Sandal Private Museum. Access: Access to science, business, innovation in digital economy, ACCESS Press, 2(1): 5-16.

https://doi.org/10.46656/access.2021.2.1(1)

\section{INTRODUCTION}

This paper is part of the study of scientific course with the institute. Initiation by institutions and the individual representing the institution like Fil. Dr. Jan-U Sandal Institute is important to be documented and preserved for reference of education for future generation. In this paper brief discussion on the institute's initiation on scientific study on social entrepreneurship has been discussed while highlighting the museology and its important aspects with literature review followed by discussion on findings and the ending up with conclusions.

Museum is generally taken as an institution involved in collection, conservation and exhibition of an object of high interest and lasting value. The categories of such objects may include art, cultural, historical, natural, 
and scientific and many more. Museum science also called as museology is the branch of scientific study of any of the aspects of museum object.

Among the lot of previous literature studies on the contribution of independent scientists in social transformation process through their act of innovation seem lacking and somehow neglected. This is very important because artifacts are also created by these scientists in the production function. These artifacts also need to be preserved for education. This paper is purpose to contribute the gap.

Independent scientist does not work in a beset of government or public sector. Moreover, public museums are governed under a given selected legacies, hence rarely bothered to promote and preserve work of such independent individuals, as a result, private museum emerges. Sandal Private Museum is also one of such initiations. In this paper along with the general review of museums initiation of social entrepreneurship education by Prof. Sandal and its connection with Nepal as well as establishment of Sandal Private Museum has also been discussed. The following are the specific objectives of this paper

A. To enquire into the various aspect of Museum Science and

B. To review the achievements of Social Entrepreneurship IBS education program in Nepal.

C. To analyze the involvement of Fil. Dr. Jan-Urban Sandal Institute, Norway in promoting museum science.

The methodology applied for this paper is review of literature including the including the internet sources and cases as well as and interview and discussion with people related to the Social Entrepreneurship IBS education program implementation in Nepal.

\section{Discussion and Analysis}

Museology is the study of museum. It is an important part of subject of science and an interesting topic for scientific study. Museology helps to explore the history of museums and its importance to the society and its conservation. While the term 'Museology' is more prevalent, it is also called as 'musiographia', 'museum practices', 'museum studies', and 'operational museology' (Wikipedia, 2020b). Wealthy individual's private collection is the early form of museum. Ennigaldi-Nana's museum is one of the oldest museum built at the end of Neo-Babylonia Empire date backs of 530 BCE (Wikipedia, 2020c). The Ashmolean in the Oxford is the first public museum (Parris, 2017). Various types of objects with historical, religious, economic, technological features and objects from many other areas of the features are acquired in the museum because these objects create important messages (Avaro, 2010) about creation of these objects and their features.

Museum is a place of intercultural dialogue. Intercultural dialogue is a process that provided open and respectful exchange of ideas and interactions between the individual and group of individuals and organizations with diverse cultural background and world views (Bodo, Gibbs, \& Sani, 2009). Museums today are not the mere place for conserving the past treasures or displaying art and science product rather an area for informal education and effective tool for communicating the mass culture (Günay, 2012). One important aim 
for many science centers, science museum and natural history museums is to contribute in science learning (Hauan \& Kolst $\varnothing$, 2014). Museology covers all aspects of museums; hence, it is the science related to study of museum in totality. But there is no uniformity in the curriculum of museum studies among the universities (Soni, 2004) which may attract important contributions of museum scientists and educationist in unifying the curriculum and system of education. For students museums provide opportunities for active participation in simulation setting by manipulating the real objects which enhances the conceptual learning in the classroom as these components of learning are significant for their understating of complex science concepts (RameyGassert, Walberg, \& Walberg, 1994) as this gives first hand description of the object of education.

Neil MacGregor, Director of British Museum (2015) opines museum is a point which allows citizens to be better citizen. With access to the museums and galleries, individuals are allowed to enter and think the another world, see the world from somewhere else and reimagine themselves and their own world (National Museum Director's Council, 2013). Such eyewitness of the real world provides opportunities to understand the things deeply.

Museums consists tangible and intangible objects. According to Koichiro Matsura, Director General (1999) of UNESCO all tangible heritage embodies intangible components like spiritual values, meanings, knowledge, symbols, or know how of craftsmanship and construction. The intangible cultural values embodied in tangible heritage are recognized as integral components of world heritage (Matsura, 2010). Museum is concerned with all tangible as well as intangible objects, because all of the tangible objects embody an idea, environment, circumstances or other phenomena with utmost importance of collection, preservation, documentation and exhibition for education.

\subsection{Museology and its Important Aspects:}

\section{Collection Management:}

In museum science collection management is administrative responsibilities of collection, care and physical preservation of artistic work. It involves the development, storage, preservation, ensuring long term safe and sustainability of collection of cultural heritage. Nowadays, collections are managed through software, the Collection Management System having standard features like Cataloging, Acquisitions, Deaccessions, Loans, Conditions and Conservations Reports, Security, Copyright and Multimedia (Wikipedia, 2020a) . Collection and collection management is the first and foremost important aspect of museology.

Since 1970s, the world of museum has gone radical changes and the attention of museum professional has been shifted from their collection towards visitors. Thus, 'new museology' has been identified within the profession due to the climate of increasing reflexivity (Ross, 2004). Horizon of every field of scientific study is to increase every day as a natural process. As a result practitioners of museum science have been developing as unique and prestigious professional. 


\section{Documentation and Conservation Management:}

Documentary prepared by Sagarmatha Television (STV) as uploaded by Pramod Sedhain in YouTube shows that the Nepal Museum in Chhauni has not only 13 crores (130 million) years old Lycoptera gifted by China to Nepal, but also Nepal's flag carried to moon in Apolo XVII mission gifted by President Nixon on behalf of the people of the USA to the Kingdom of Nepal along with a piece of rock of moon (STV, 2011). These altogether represents the act of conservations in museums for the education of future generation

Documenting the existing conditions of the object of museology is the most important step in conservation process. For every object that are taken into the conservation process are documented (Barok, Noordegraaf, \& de Vries, 2019). When an object is arrived at the museum it is entered in the 'Entry Register' denoting its identification as gift, purchase, loan, transfer or whatever with name, address and signature of the depositor and specific accession number is allotted to the objects entered (Avaro, 2010). Trinomial numbering system is used where normally the first number denotes the year of accession, second number denotes the type of object and the third is the object number (Sonoda, 2016). Document can be evaluated itself considering the symbolization of an even or individual or certain identity as an icon (Allyn, Aubitz, \& Stern, 1987). Large extent of the value, safety and accessibility to the object in the museum depends upon its documentation. Documentation is the organization of the information pertaining to the object in the museum which enables the museum about proof of ownership, location of object, number of objects making up the collection and its inventory, establishing the identity of the object, linking the information pertaining to it with access to the information, contributing to the safety of the collection and carrying out an insurance valuation (Avaro, 2010). Growing presence of artistic work in the museum collections is increasing the importance of documentation and collection management systems has limitation in adequately presenting rich form of documentation (Barok et al., 2019). Documentation is crucial before the objects enters the museum and in regular practices as well (Lourenço \& Gessner, 2014). Documentation and conservation follows back and forth process. Conservations are documented and documents are conserved.

\section{Exhibition Management:}

To make objects of the museum accessible and available to the public is the fundamental mission of any exhibition. Important way of providing access to such objects in the museum and to understand its cultural heritage is exhibition. Similarly, exhibition provides opportunities to the historians, curators and archivists to fulfill their obligation to educate a broad spectrum of society consisting scholars, curious children and adults (Allyn et al., 1987).Greater attention should be given and innovative approach is needed to provide satisfactory solution to address the question of archiving exhibitions (Knecht, 2014). Emphasizing the outreach access by those who are unable to visit museum can be enhanced. This can help with the growth of new museum pedagogy and the cultural democratization of the museum (Joshi, 2018) for education. 
Developments in society influences museums (Knerr, 2000). Museums collects, conserves, documents and exhibits the past treasure of art, science culture, history and many more aspects of development achievements along social transformation process in human society. Museum Science and its effective partnership with educational institution have beneficial to the students. We can find many studies with the objectives of analyzing the impact of museum activities on the scientific knowledge and nature of science. The important finding of such studies were that activities involving museum science is important not only to promote the understanding of scientific concepts but also to stimulate the development of knowledge about science and construction of scientific knowledge (Faria, Guilherme, Gaspar, \& Boaventura, 2015). In the last couple of decades educational role of museums has been rushed worldwide due to the reason that museum education being a unique discipline with roots in various field science has been acknowledged (Xanthoudaki, 2002) and every segment of the society is being more concerned about the connection between museums and knowledge base.

Science is a way of thinking. Museum science and concept of independent science seems to be connected. Fundamental of the concept of independent science is that science is intuitive and not relied upon other's work. Similarly theory of independent science is managed by individual and not by institutions (Sandal, 2016) and it is free from any influence from any religious, political and cultural values. Independent science is an individual's knowledge and his intuitive act that any scientific result comes out of his work. The world economy today fostering economic growth and social change has wide range of recognition of the importance of knowledge and intellectual capital. But this status has been attached with a challenge to devise an appropriate useful way to measure the importance of knowledge and intellectual assets. In every stage of the production process key components of knowledge economy includes a greater reliance on intellectual capabilities. Independent science has indispensable contribution to the economy and knowledge industry; and the acts of independent scientists keep going on irrespective of political or other mindset of the society (Nepal, 2017). The crux of this idea is that knowledge and work of independent scientists as shall be collected preserved and managed in an effective way that ensures its availability for the education of future generation.

\subsection{Fil. Dr. Jan-U. Sandal Institute and Social Entrepreneurship IBS education in Nepal}

Fil. Dr. Jan-U Sandal Institute has scientific research activities in many countries. The Institute comprises three separate departments for social science, education and culture. The institute is building its network with international universities and currently this network has 8 universities and colleges with 85 thousand students and 20 thousand faculty members (Sandal, 2016). Prof. Fil. Dr. Sandal has been running the institute as its Owner and Rector. He lectures the Social Entrepreneurship School IBS. IBS stands for the Innovation, Business and Society. The 20 weeks full time program of the course consists of the following part:

A. International Study course in Social Entrepreneurship 


\section{B. International Study on Innovation Management \\ C. International Study Course in Service Management}

After completion of the course followed by examinations the participating students graduate and having signed the Certificate receive the award and the title of Diploma in Social Entrepreneur IBS along with the Glass Statuette as the Insignia of Graduation. The importance of such initiation of international education that too on voluntary basis without any motive of economic gain is important in broadening the horizon of scientific education on entrepreneurship because it paves the way for thinking globally and acting locally for the students and professionals participating in the program.

Social entrepreneurs are individuals who voluntary involve is any innovative idea, work or initiation without initial motive of making profit. But express or implied objective of their effort is social transformation to make everybody's life easy. If their initiative is proven successful they gain economic benefit from their innovation. There are various important aspects of social entrepreneurship which helps any prospective social entrepreneur to learn about managing entrepreneurship to face challenges and to create opportunities.

The institute provides fellowship program as well. There are different categories of fellowships provided. This includes the Affiliated Scientific Fellowship, Affiliated Honorary Research Fellowship and Honorary Senior Fellowship. Affiliated Honorary Research Fellowship can be provided to the Social Entrepreneurship IBS graduated upon completion of further scientific course and fulfillment of the criteria as decided by the institute. Various study course module have been given under this fellowship category. Museology as an integral part of the affiliated honorary research fellowship program has been studied with the Fil. Dr. Jan-U. Sandal Institute.

Fil. Dr. Jan-Urban Sandal made first exchange visit to Nepal and had Memorandum of Understanding with the South Western State College, Basundhara, Kathmandu for scientific collaboration in education of all levels (Sandal, 2016). Since then many batches of the students, professionals and senior professionals from various sector of Nepal have been graduated from the program. The Social Entrepreneurship IBS program conducted by institute at the SWSC, Basundhara, Kathmandu three different courses Social Entrepreneurship, International Study Course on Innovation Management and International Study Course on Service Vision Management. The study method consists of lectures by Prof. Sandal and group works and presentation. Altogether 20 lessons are taught and study completes with final examination. Since the program was started in 2017, four batches of students comprising altogether 97 (36 in February 2016 batch, 26 in September 2016 batch, 12 in 2017 batch, 17 in 2018 batch and 6 in 2019 batch) individuals have $\backslash$ graduated in Social Entrepreneurship IBS so far from the SWSC (Fil.DrJan-U.Sandal_Insitute, 2020). This number of graduates can contribute immensely in further promoting the social entrepreneurship education which can give good results in promoting social entrepreneurship and new innovation in Nepali society. 


\subsection{Museum and Work of Independent Scientists}

Tangible heritages are not only the object of museology. Treasures of intangible nature like intellectual achievements and work and effort of independent scientists are of great importance from the viewpoints of human civilization of social transformation process. Further revolution in the information technology sector shows intangible heritage pertaining to the evolutions are also necessary and possible to preserve for the education and benefit of future generation.

Museum has been recognized as broader learning and knowledge institution for the society (Ahmad, Abbas, Yusof, \& Taib, 2013). Preservation of the contribution of scientists is important to assure the preservation of intellectual contents of the scientific work. Museums today are important places of preserving natural, scientific, historical, cultural and all other heritage.

Government cannot do the same as independent scientist and entrepreneur for innovation. Museum Science is also rooted in analyzing the work of entrepreneur and independent scientist (Sandal, 2019a). Entrepreneurs are the creators of the civilization. It is the function of entrepreneur which creates entrepreneurial profit through addition of innovation. Over the time, entrepreneurial profits vanished. Any object representing the work of independent scientists become artifacts after the production is over and productive use of the object is over. Therefore, when the innovation is ended the nature of production means needs to be treated as artifacts. Independent scientists creates artifacts through production function,(Sandal, 2019b), which needs to be preserved for education of future generation. The work of independent scientist is not under any auspices of the government or any other public entity or organization. So, doing such work in the society the scientist may not come under the general rule, process or practice of the government, it may also be true the government might not be interested. But the preservation of such artifacts has far reaching importance from the view point of development of civilization and social transformation process.

Western museums are linked to colonialism, imperialism and European Missionary work (Wikipedia, 2020b). Many museums around the world are having controversies surrounded by cultural imperialism and nationalism and issues relating to right over the possession of artifacts. The issue is complicated when question raised whether a person can sell or destroy an antique item of significant cultural and historical value found in his/her backyard (Do, 2019). The questions is still more pertinent about the stolen and owned museum treasures in the US and European (especially the British Museum) countries belonged to non-western countries in the past (Little, 2018). Taking an example from Nigeria, some 4000 sculptures were stolen by British troops after invasion of the Kingdom of Benin are being displayed after centuries later in UK, USA, Austria and Germany, but none in Nigeria (Little, 2018). Lots of priceless treasures including those dates back to $200 \mathrm{AD}$ looted from south-eastern India are in British Museum (VicStefanu, 2018). These museums are mourning pressure to return the looted priceless treasures in colonial times (Horton, 2018). There are also cases of dislocation or disappearance of the antique heritage from its place of origin due to different reasons. Nepal in history was very successful to stop the colonial and imperialist forces in its territory. Unlike the case of looting 
from colonialized countries, Nepal is still facing the problem of stealing generally and sometimes plundering as well of the antique objects. Kathmandu Valley Protection Trust (KVPT) reports, stealing of such treasures in modern time is continued as 54 significant sculptures, woodcarving and icons from Nepal are stolen within a 18 months period (KVPT, 2020). This clearly indicates the threats on preservation of such antique objects.

History shows artifacts from around the world have been stolen and collected in museums or private collections in places other than those where the objects were created. No less than 90 per cent of the African cultural heritage now resides in museums in European countries (Robertson, 2020). One example, as Mark Hurton described, none of the African artifacts stayed there but scattered in museums and private collections around the world. The British museum holds almost 40 percent of the haul (Horton, 2018). Another example, many of the $15^{\text {th }}$ century idols of Nepal have been stolen from its old city Patan which have been found in Dallas Museum (Baral, 2019). This is only a sample case from thousands of Nepali art and craft stolen.

It has been found that public museums are harshly often judged for chosen heritage selected by their key decision makers (Brown, 2017). Currently, culture landscape is being changed as the privately owned museums are on continuous rise (Brown, 2017). Private museum historically was started some times as per the whim of looters and most of the time according to their planned looting to collect the artifacts. However, need of modern time is where the government finds itself least bothered to preserve the individual scientific artifacts, current private museums have emerged.

\subsection{Sandal Private Museum}

A private museum is operated by enthusiasts individuals, collectors, club or companies unlike government or public museum (Wikipedia, 2020d). As discussed earlier, the basic purpose of any museum is to collect for preservation, management of utilizing the cultural, historical, scientific, natural, artistic or any other such object for the education of public at large. We can observe various categories and types of museums. Once of such categories is the public and private museum. Public museums are understood as museums sponsored by the government generally. Unlike public museum private museum are not funded and supported by any public authorities or government.

Fil. Dr. Jan-Urban Sandal Institute on $17^{\text {th }}$ August 2018 consecutively decided to open Sandal Private Museum. In order to secure long term financing, museum fund has also been erected on September $6^{\text {th }}$ of the same year. The museum is located at the institute campus\#2 where a large number of artifacts have been accumulated (SandalMuseum, 2018). The museum was inaugurated by the Vietnamese Embassy Minister Counselor amidst a program attended by the foreign prominent scientists, professors, students and guest on $15^{\text {th }}$ June 2019 (SandalMuseum, 2019). The mission statement of museum mentions with their judgmental decisions entrepreneurs create innovations and they are the creators of civilization, therefore, it is extremely important to study of their life and work for deeper understanding of the innovation process. 
We can find questions pertaining to relevance of private museums. It has been stated that private museums have relevance on historical research only and only if it can complement to national collections (Wikipedia, 2020d). This may be just one of the ideas among all other ideas justifying the private museums. Further, preserving new innovative contributions of social entrepreneurs has significant relevance with historical content of research and can complement the effort on which government would have been involved.

\section{CONCLUSION}

Museum is science is an important part of the scientific learning of universal body of knowledge. Collection Management, Documentation and Conservation Management and Exhibition Management are important aspects of museology and museum science. Basic motive of museology is collection, preservation and management of tangible and intangible form of natural, historical, cultural and scientific objects as well as intellectual work and knowledge in an effective way that ensures its availability for future generation. Museum science is a science which collects preserves and manages output of every scientific field. Museum history has notorious stories of stealing and looting.

Public museums can be judgmental on the museum object based upon selection of its key decision makers. As such an achievement pertaining to independent scientific work may be left behind from preservation which is immensely important from the view point of collection, conservation, documentation and exhibition of the milestone achievements of social transformation process. Globally contribution of social entrepreneurship is somehow neglected while focusing in business entrepreneurship. Fil.Dr. Jan-Urban Sandal Institute is contributing to independent social scientists movement. After his own learning process Prof. Sandal started global education program on Social Entrepreneurship. Through the institute educational programs on social entrepreneurship to the individual from the entire sphere of scholars, professors, universities, practitioners, political and governments are effectively going on. Nepal also has benefited from this initiation Prof. Sandal. More importantly, the start of Sandal Private Museum is breath of fresh to social scientist all over the world but it needs time to work for preserving independent scientific achievements with global perspectives.

\section{Acknowledgements}

This article is the edited version of the scientific paper created at the Fil. Dr. Jan-U. Sandal Institute, Norway under supervision of Prof. Fil. Dr, Jan-Urban Sandal. The author is utmost grateful to Prof. Sandal for the guidance provided.

\section{Conflict of Interest:}

The author declares that there is no conflict of interest. 


\section{References}

Ahmad, S., Abbas, M. Y., Yusof, W. Z. M., \& Taib, M. Z. M. (2013). Museum Learning: Using Research as Best Practice in Creating Future Museum Exhibition. Procedia - Social and Behavioral Sciences, 105, 370-382. https://doi.org/10.1016/j.sbspro.2013.11.039

Allyn, N., Aubitz, S., \& Stern, G. F. (1987). Using archival materials effectively in museum exhibitions. American Archivist, 50(3), 402-404. https://doi.org/10.17723/aarc.50.3.g5203123461g2208

Avaro, A. A. (2010). Documentation of Museum Collections. Why? How? Practical Guide. ICCROM-UNESCO PARTNERSHIP FOR THE PREVENTIVE CONSERVATION OF ENDANGERED MUSEUM COLLECTIONS IN DEVELOPING COUNTRIES I, (April), 23. Retrieved from http://epa-prema.net/documents/ressources/PracticalGuide-Documentation_eng.pdf

Baral, A. (2019). 15th Century Idols Stolen from Patan Durbar. Retrieved August 17, 2020, from myRupublica website: https://myrepublica.nagariknetwork.com/news/15th-century-idol-stolen-from-patan-spotted-in-dallasmuseum/\#: :text=KATHMANDU\%2C Nov 21\%3A An idol,art crime\%2C tweeted on Tuesday.

Barok, D., Noordegraaf, J., \& de Vries, A. P. (2019). From Collection Management to Content Management in Art Documentation: The Conservator as an Editor. Studies in Conservation, 64(8), $472-489$. https://doi.org/10.1080/00393630.2019.1603921

Bodo, S., Gibbs, K., \& Sani, M. (eds. . (2009). Museums as places for intercultural dialogue: selected practices from Europe (M. S. Simona Bodo, Kirsten Gibbs, Ed.). Retrieved from http://www.nemo.org/fileadmin/Dateien/public/service/Handbook_MAPforID_EN.pdf

Brown, K. (2017). Public vs Private Art Collections who controls our cultural heritage.pdf. Retrieved August 22, 2020, from https://theconversation.com/ website: https://theconversation.com/public-vs-private-art-collections-whocontrols-our-cultural-heritage-80594

Do, M. (2019). Why Artifacts Belong In Museums. Retrieved August 17, 2020, from Freeely Magazine.com website: https://rreelymagazine.com/2019/04/03/why-artifacts-belong-in-museums/\#: :text=The museum is transparent about,educating the public about them.\&text=At the end of the, $\% 2 \mathrm{C}$ countries $\% 2 \mathrm{C}$ and political beliefs.

Faria, C., Guilherme, E., Gaspar, R., \& Boaventura, D. (2015). History of Science and Science Museums: An Enriching Partnership for Elementary School Science. Science and Education, 24(7-8), 983-1000. https://doi.org/10.1007/s11191-015-9773-7

Fil.DrJan-U.Sandal_Insitute. (2020). Graduation. $\quad$ Retrieved July $\quad 25, \quad 2020, \quad$ from https://janusandal.no/en/school/graduation

Ghimire, R.P. (2020). Scientific Enquiry into the Flat Social Media Innovation based Modelling of Flat Social Entrepreneurship for Economic and Non-Economic Opportunities. Access journal, ACCESS Press, 1(1): 31-38, DOI: https://doi.org/10.46656/access.2020.1.1(2)

Günay, B. (2012). Museum Concept from Past to Present and Importance of Museums as Centers of Art Education. Procedia - Social and Behavioral Sciences, 55, 1250-1258. https://doi.org/10.1016/j.sbspro.2012.09.622

Hauan, N. P., \& Kolst $\varnothing$, S. D. (2014). Exhibitions as learning environments: a review of empirical research on students' science learning at Natural History Museums, Science Museums and Science Centres. Nordic Studies in Science Education, 10(1), 90-104. https://doi.org/10.5617/nordina.652

Horton, M. (2018). Is it time looted artefacts are returned to the cultures that made them? Retrieved August 22, 2020, from https://www.weforum.org/ website: https://www.weforum.org/agenda/2018/11/returning-looted-artefactswill-finally-restore-heritage-to-the-brilliant-cultures-that-made-them

Joshi, A. (2018). Revisiting Museum Education - Experience, Process, Pedagogy and Performance: Developing outreach agenda in Indian museums - A theoretical framework. In M. Seth (Ed.), Of muses, museums \& museology (pp. 1125). New Delhi: National Museum Institute (Deemed University), Shubhi Publications Gurugram - India.

Knecht, S. and N. C. (2014). Documenting exhibitions - a case study from the Olympic Museum , Lausanne. Conference: CIDOC 2014At: Dresden, $\quad$ (November), 1-10. Retrieved from https://www.researchgate.net/publication/268148671_Documenting_exhibitions__a_case_study_from_the_Olympic_Museum_Lausanne

Knerr, G. (2000). Technology museums: new publics, new partners. In Marcia Lord (Ed.), Museum International (No. 4, Oct, pp. 1-72). Retrieved from http://www.unesco.org/new/en/natural-sciences/science-technology/single-view- 
sc-policy/news/unesco_promotes_access_to_science_for_sustainable_developmen/

KVPT. (2020). Stolen Arts of Nepal.pdf. Retrieved August 17, 2020, from Stolen Arts of Nepal website: https://kvptnepal.org/

Little, B. (2018). Will the British Museum Ever Return the Stolen Artifacts.pdf. Retrieved August 17, 2020, from History.com website: https://www.history.com/news/british-museum-stolen-artifacts-nigeria

Lourenço, M. C., \& Gessner, S. (2014). Documenting Collections: Cornerstones for More History of Science in Museums. Science and Education, 23(4), 727-745. https://doi.org/10.1007/s11191-012-9568-Z

Matsura, K. (2010). Preface to Intangible Heritage. In I. D. M. Vinson, D. G. S. Z. Condominas, \& Stephen et. al (Eds.), Museum International (Vol. 62, pp. 4-5). Published by Blackwell Publishing, 9600 Garsington Road, Oxford, OX4 2DQ (UK) and 350 Main Street, Malden, MA 02148 (USA) ISSN 1350-0775, no. 221-222 (vol. 56, no. 1-2, 2004).

National Museum Director's Council. (2013). Museums Matter. Museums Matter. https://doi.org/10.7208/chicago/9780226126807.001.0001

Nepal, A. (2017). Independent Science and Knowledge Industry. ROLE OF HIGHER EDUCATION INSTITUTIONS IN SOCIETY: CHALLENGES, TENDENCIES AND PERSPECTIVES, 1(Nr. 1 (6) Issn 2029-9311), $200-205$. Retrieved from http://www.akolegija.lt/

Omarov, E. 2020. Social entrepreneurship and what does it mean for management of consumer behavior. Access journal, ACCESS Press, 1(2): 86-102, https://doi.org/10.46656/access.2020.1.2(1)

Parris, C. (2017). The story of the world's first public museum. Retrieved October 1, 2020, from Ashmolean Museum Oxford website: https://www.ashmolean.org/article/the-story-of-the-worlds-first-public-museum

Ramey-Gassert, L., Walberg, H. J., \& Walberg, H. J. (1994). Reexamining connections: Museums as science learning environments. Science Education, 78(4), 345-363. https://doi.org/10.1002/sce.3730780403

Robertson, G. (2020). It's Time for Museums to Return Stolen Treasures. Retrieved August 22, 2020, from CNN Style website: https://edition.cnn.com/style/article/return-stolen-treasures-geoffrey-robertson/index.html

Ross, M. (2004). Interpreting the new museology. Museum and Society, 2(2), 84-103. Retrieved from https://www.researchgate.net/publication/253131193_Interpreting_the_new_museology

Sandal, J.-U. (2016, March). Independent Science is Managed and Developed by Individuals not by Orgnizations. RevoScience. Retrieved from www.revoscience.com/en

Sandal, J.-U. (2019a). Museum Sceince and Sandal Private Museum. Retrieved from https://janusandal.no/en/museum/publications

Sandal, J.-U. (2019b). Museum science and the Creation of Artifacts Based on the Production Functio. PROBLEMS OF SCIENCE AND PRACTICE Dedicated to the Outstanding Scientist-Economist Fr. G. Lieberman Abstracts of Reports of the International Scientific-Practical Conference, 447-450. Retrieved from https://janusandal.no/no/museum/publications

Sandal Museum. (2018). Histoy of Sandal Private Museum. Retrieved August 20, 2020, from SANDAL PRIVATE MUSEUM website: https://janusandal.no/en/museum/history

Sandal Museum. (2019). PRESS RELEASE Inauguration. Retrieved August 20, 2020, from Press Release Inaguration website: https://janusandal.no/en/about/pressrelease

Soni, A. (2004). Museology: An area of study and Research. Journal of Indian Museums, L VII(January 2004). Retrieved from https://www.researchgate.net/publication/334772999_Museology_an_area_of_study_and_research

Sonoda, N. (2016). New Horizons for Asian Museums and Museology. New Horizons for Asian Museums and Museology, (July 2015), 1-204. https://doi.org/10.1007/978-981-10-0886-3

STV. (2011). Chhauni Museum- Nepal. In Sagarmath Television. Retrieved from https://www.youtube.com/watch?v=2u747RGV8sc

VicStefanu. (2018). British Museum: Lots of Looted \& Priceless Indian Treasures (London). Retrieved August 24, 2020 , from Youtube website: https://www.youtube.com/watch?v=9Ts2P12JWyA\&t=575s

Wikipedia. (2020a). Collection Management. Retrieved June 3, 2020, from Collection Management (Museum) website: https://en.wikipedia.org/wiki/Collections_management_(museum)

Wikipedia. (2020b). Museology. Retrieved May 17, 2019, from https://en.wikipedia.org/wiki/Museology 
Wikipedia. (2020c). Museum. Retrieved September 30, 2020, from Wikepedia website: https://en.wikipedia.org/wiki/Museum

Wikipedia. (2020d). Private Museum. Retrieved August 20, 2020, from PRIVATE MUSEUM website: https://en.wikipedia.org/wiki/Private_museum

Xanthoudaki, M. (2002). Introduction. In M. Xanthoudaki (Ed.), A PLACE TO DISCOVER: TEACHING SCIENCE AND TECHNOLOGY WITH MUSEUMS. https://doi.org/10.22323/2.02040701

\section{About the author}

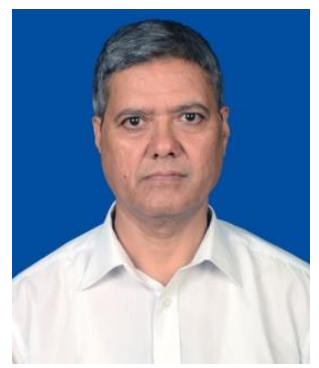

Achyut NEPAL is Affiliated Honorary Research Fellow of Fil. Dr. Jan-U. Sandal Institute, Norway. Currently, Achyut is a freelancer finance professional after serving more than thirty-five years of work experience with various organizations in different sectors of Nepal, including government, I/NGOs, and Corporate sector. His engagement with the organizations includes services as an employee occupying senior management positions, as well as an independent individual consultant.

Research interests: economic development, social entrepreneurship, museum science, museology, independent science, economic history.

ORCID ID: https://orcid.org/0000-0003-2597-6037 